\title{
Folk-beliefs and Folk-healing in Rural Turkey
}

\author{
Sinan Çaya \\ Institute of Marine Administration and Sciences, Istanbul University, Vefa-Istanbul 34134, Turkey
}

Received: December 24, 2014 / Accepted: January 10, 2015 / Published: January 30, 2015.

\begin{abstract}
Peasants in Turkey are mostly wise, worldly, down-to-earth people. Superstitions do play a role in their line of thinking though it is not only the peasant mind which is exclusively preoccupied with superstitions. Peasants' other beliefs mostly fall into the scope of religious creed. Folk healing is mingled with some beliefs but some healing methods are just primitive but consistently logical modes of treatment of diseases and if people resort to them, it is mainly because of the inaccessibility of modern medical ways. Folk healing, besides, is being replaced by modern treatment more and more.
\end{abstract}

Key words: Belief, Islam, healer, folk, peasant, Turkish.

\section{Introduction: Respect for the Holy}

Villagers in Turkey are mostly conservative people and they honor holy places. Shrines of saints are visited and prayers are addressed to Allah in their sacred presence with the formula "for the sake of this holy person bestow me with such and such wish, my God!" Both Sunnite and Alewite denominations recognize their own respective saints. The Salafia sect and its extension Wahhabi sect from continental Arabia consider this a sinful novelty spoiling the religion and equates it with putting up a partner-never ever/jamais!-to God Almighty, which is a horrible $\sin$.

However, besides the Wahhabis, many Islamic scholars see no wrongdoing in the veneration of the Blessed Prophet's apostles, saints and martyrs. They stress that the institution of intercession (şefaat) is valid in religion. As long as a divine request is not directed to the saint himself, they argue, it is only a blessing to visit them and put them as go-betweens. They stress that worshipping is different from respecting.

It is said that the Blessed Prophet got his hair

Corresponding author: Sinan Çaya, Ph.D., research fields: leadership, forensic studies, rural sociology, general education, peasant studies. E-mail: sinan.caya@gmail.com. cropped and distributed to the Moslems all over. His glorious beard clippings, too, are believed to be preserved in some prominent mosques.

According to the Islamic faith, miracles were bestowed solely upon the prophets. No more prophets will be sent. The era of miracles is closed. A miracle is a supernatural phenomenon realized by Allah as a reply to the given prophet's own wish and prayer.

As for the saints, they can only perform wonders (kerâmetler) —and this they can achieve even after they die-which are not on "wish or bargain", so to speak, but come about unexpectedly, even its instigator-saint not knowing if or when they will occur.

A wonder attributed to a republican-era Çankırl-saint (who constitutes a rarity since most Islamic shrines date from Seljukid or Ottoman times in Çankiri or for that matter in the entire Anatolian peninsula) goes as follows:

During the Cyprus peace operation carried out in 1974, a well-liked soldier appeared from time to time among the soldiers of a certain platoon as if visiting them from an adjacent platoon. He fraternized with a few soldiers and invited them to his home city in case they would survive the war.

Some years later a couple of those friends happened to pass by Çankırı and they wanted to pay a visit to their mutual comrade-in-arm. The name 
(Astarlizâde Mehmed Hilmi) did indeed sound well-known enough in the city, as formerly assured by their comrade.

But they were eventually led to a tomb instead of a living person! So, they thought their friend had passed away in the mean time. But what?

The date of death inscribed on the stone was only 1962, a time more than a decade before the operation in Cyprus! Only then they realized that their military comrade was a saint, who had risen from his tomb to take place in the battle!

Alewite villagers are usually much less conservative and possess a "wider" disposition in delicate matters representing strict taboo for the Sunnite ones.

When I was a tailor's apprentice, a Geselle (journeyman, senior apprentice, kalfa) working on a piecewise system was a young Alewite man. Our Meister (usta) one day wanted to take him along to the Friday prayer in the mosque and he retorted: "C'mon now! Stop teasing me! Stop playing around with a poor being like me!" Then he looked up and mumbled: "I hope a colossal beam from the ceiling won't fall on my head, now!" The Meister laughed and left him alone (He always appreciated his young helper's sense of humor a lot).

Once an Alewite peasant customer had ordered a suit. He was a burly man always displaying a subtle smile on his reddish face and he had jovial, even exuberant manners.

One day at the trial of his half-finished jacket, he said that in the village a married woman with a tall bearing and serious look appealed to him; so he went to her husband and jokingly said "well, comrade, what about the idea of tramping my woman with yours?"

The joke came to the attention of the woman in question and she escaped in horror from her house to her own village to take shelter in the maternal nest for a certain time.

All this was told among intermittent laughter fits by the man himself, in the tailor shop. A typical Sunnite man can never make such a suggestion or relate such a memory to others in such a light-hearted manner.

\section{Association Between Health and Creed}

Folk healing for peasants has two dimensions. One is "reasonable and rational" and is resorted to because of necessity like practicality, unavailability of health professionals, lack of money, etc. The other dimension has to do with producing or overcoming magic and follows a totally different line of thought, or rather belief. Incenses, lead pouring ${ }^{(*)}$, various amulets, drinking or smearing on the skin obviously filthy and microbe contaminated stuff like remains of a dead hedgehog or donkey's urine ${ }^{(* *)}$ involve this sort of "cure". Some methods are a mixture of the two dimensions.

Turkish peasants are also mostly superstitious people although being superstitious is not exclusively a peasant-like trait. Rather it may be more correct to consider it a personal trait of many a people in the bosom of the modern society.

The military might of Prussians was admired by the later Ottomans. The superstitious sultan, Mustapha III (1757-1774) once asked Frederic II to send him three astrologers (fortune-tellers) as military advisors. The emperor replied that his astrologers were his staff officers and gave the following advice: "The sultan should study history, evaluate the former experiences and possess a good army". This should not appear as such an horrifying case of ignorance for the times. Though not totally relying on fortune-telling, many kings were known to touch the concept. In a historical novel Barbara Cartland depicts Napoleon himself as a superstitious man in need of the advice of his astrologers.

A movie released in 1961 and directed by Frank Capra starring Glenn Ford (Dave the dude), Bette

\footnotetext{
* Some years ago Belly Dancer Asena got shot on the stage by an angry fan. She suffered a lot but finally totally recovered. In a recent interview on TV she proved her humorous wit by saying "I got lead poured" and chuckled over the adventure (In Turkish the words "lead" and "bullet" are homonymic).

${ }^{* *}$ In Actpayam region swollen tonsils are treated by gargling donkey's urine in the mouth (Ac1payaml1 1982: 15).
} 
Davis (Apple Annie) deals with superstitious beliefs in the background. The title was Pocketful of Miracles and the Turkish title was Elmacl Kadin (The Apple-Selling Woman). Annie is a peddler selling apples in depression years and bootlegger Dave buys one apple every time he encounters her. He believes her apples will bring him good luck. On day he finds Annie in tears. It turns out that she has a young daughter, a student in Spain since infancy. The girl thinks her mother is rich. She is coming for a visit with her noble fiancé. The gangster needs her to sustain his luck and decides to help her.

Accordingly his close circle collaborates to prepare a mise en scène. A cultured billiard player hooligan becomes Annie's husband. Curious journalists who sense something fishy and interfere are kidnapped and tied by Dave's mob. A spectacular reception succeeds to fool the guests and they are impressed. Meanwhile, the police are searching the missing journalists and Dave's girlfriend Queenie's nightclub is surrounded by police. Dude makes a deal with the police chief and takes him into the conspiracy. Luck also helps. The people at the coincidental party for the mayor, show up for Annie's reception. At the end, the daughter and her escort return happily by ship to get married back in Spain.

Before the return one problem was the issue of drahoma, the "anti-dowry". Like in Greece, in Spain the girl's party pays a groom price in contrast to bride price more common around the world. But the prospective father-in-law, the count, is a billiard freak. Annie's false husband beats him in a billiard party and that financial problem is also settled.

\section{Certain Health "Recipes"}

The rational treatment involves a "pharmocopea" or recipe where certain diseases are matched with certain ingredients, mostly of herbal nature. For instance in Actpayam if the menstrual cycle is cut off [at a young age] the patient drinks a boiled extract of harmal plant (üzerlik) seeds; A coughing patient drinks the hot extract of elder (mürver) tree's flowers [1].

Some rational folk treatment methods involve physical handling instead of taking organic chemicals into the digestive tract. One such method is pulling cups on the aching body region. The section of the body in question is cleaned. A piece of cotton is burned and a cup or bottle is covered over the flame. When the oxygen content of the imprisoned air (21\%) is consumed the resulting vacuum sucks and elongates the skin locally. Some capillary blood diffuses out. After a while the cups are removed one by one. Modern versions of this treatment are advertised.

From the movie Zorba the Greek (starring Anthony Quinn and Alan Bates and based on a novel by Nikos Kazantzakis) filmed in a Cretan village, a related scene is in my memory. Inn-keeper old French widow gets sick and the high-spirited, joyous, life-affirming Greek peasant Zorba (my father has a touch of his character) applies this cup pulling treatment to her. In fact; when removing the cups one by one, gloom gloom; to spirit her morale, he teases her by saying "sounds sexy, does it not?". (She can not recover. When the Cretan peasants understand that she will die they rush and plunder the house, since she has no heir).

Sunar [2] relates an unsuccessful folk healing in one village with an educator (educators were unschooled, course graduated preliminary teachers) as a memory: $I$ knew a girl in the front row before. When I revisited the school Fatma was absent. I learned that she died meanwhile. She got a cold and her parents wrapped hot bread from the furnace on her chest and back. Moreover they tightly covered her and pressed the cover. The poor girl cried "mama, I am all burning!" but they told her to endure the beneficial heat. She got suffocated in the bed.

Bone-setting is also practiced in villages by skillful and experienced persons. A student in my junior high school in Alpullu got his wrist dislocated in his village, Lahana, on a weekend. They took him to Kavakl village of Kirklareli and the locally famous Hasan 
$A g a^{(*)}$ put his wrist in position. When I was a teacher in Eskişehir at a boarding school a dorm surveillant, Halil, got his elbow dislocated in the evening time. It was more handy to skip any hospital and go to the nearby house of the local bonesetter Hüseyin Aga. The bonesetter put the elbow in position, took Halil's handkerchief and wrapped it around. (Cloth handkerchiefs were yet in use). The irony is, Halil was a student at the Pharmacy Faculty.

An old retired government official once mentioned about his finger being deeply cut in childhood. An old neighbor rubbed off some granules from the inside suede surface of his thick leather belt. He treated the cut with those particles and wrapped. The awful cut healed almost perfectly.

\section{Healer Foyers}

When visiting Kırklareli I asked a person from the same village about the cairopractor of my childhood days. He said the old man died but his son Naci took over the practice. Many healers come from a family, foyer, and the talent passes as a legacy from father to one of the sons.

In 1980s a certain Macit Bey from a special foyer in Tarsus supposedly specialized in driving away scorpions from a given location, became known in the media. The rumor went that President Kenan Evren's Marmaris villa was blessed by him too. But this is a mystical issue rather than sheer hand talent as a craft. Moreover, at least some mystical tinting is always

\footnotetext{
* Aga, a very humble title in Western Turkey, is different from the rich agha/ağa. It merely means elder brother. General Cemâl Gürsel was given this title by younger officers. A part-time journeyman in "my" former tailor shop, Patched Mustafa, served as a conscript under his command in İzmir. He said the general had been a fatherly figure. Once he tasted the soup during a kitchen inspection and did not find it delicious. He tilted the cauldron with his army boots and poured the content down. He ordered new soup to be cooked. The general was abused during the 1960-coup. Unlike the September 1980 coup, this was not carried out within the entire chain of command but a small junta group undertook the "task". In need of a higher rank than the junior general Madanoğlu, they fetched the retired four-star-general from İzmir by plane and put him at the top position as a front view to save the appearances.
}

involved in foyer type of healing.

In his famous novel analyzing a Central Anatolian village Makal [3] talks about different healing foyers in the vicinity of the village, specialized for different sorts of suffering, like high fever or nose bleeding etc. Sometimes one decides to choose among them through divination. One puts pins in a bowl full of water. Each pin indicates the direction of a different foyer. Whichever pin begins to rust first gives the right direction.

On a TV screen some years ago showman Mehmet Ali Erbil was confronted with his mother and stepfather, a medical doctor. The father mentioned that in Ankara he carried his step-son on his back to a healer for jaundice treatment through the "cutting" method and it worked.

Noah Gordon in his novel "The Physician" writes about a healer. The nine-year-old Scottish boy Cole is the apprentice of an itinerant barber-surgeon. He has a "gift" for sensing the approaching death when he grabs the wrists of a sick person. He travels all the way to Persia and in Ispahan becomes a student to Ibn Sina (Avicenna). Since Christians are not admitted to the Islamic Medical School he pretends to be a Jew. Another novel by the same author, "Shaman", depicts a descendant of that very boy as the hero in America during the Civil War time. He has a doctor's diploma along with the hereditary mystical gift. The gift passes to his deaf son who also begins the study of medicine.

I understand strong traditions exist in Scotland. When I was a summer-trainer in a Swiss plant as a junior chemical engineering student, my Scottish boss, Dr. Roger Page once mentioned about sewing woolen patches on the torsos of rural children in autumn and leaving them untouched until the spring, without washing the trunk. He said some families consider it more healthy. (He named the practice as being "bleached" or "bleeched" as I understood from the pronunciation and as far as I can come to spelling it; but I could never check it on any written literature, which is expected. The involved word, after all, is not contained 
in dictionaries, in that particular sense).

\section{My Own Erlebnis with Healers}

My maternal granny, originally from rural Macedonia, had some folk healing capabilities which she practiced on the insistance of some neighbors around. Her children picked up none of those talents. She used to gently rub injured points on the body with ash and yolk and then wrap. Another thing she used to do was applying mortar-beaten raw onions to wounds and then wrapping. But her distinguished practice was a little surgery. If a baby's tongue was too thick below, she would remove some of the tissue with a pin sterilized on fire and than put salt as disinfectant. This operation prevented the baby from having a lisping speech in adulthood. One time a neighbor discovered the tongue-fault too late, at a growth stage past the infancy; and my granny refused to handle the child. Based on long passed experience, she said that it could be fatal to do it on this child.

While a child in Alpullu I once acquired a lovable street puppy and soon after that wounds surrounded my face and hands. (I brought the puppy to our garden in our bread-basket; my mother found out about it from her neighbor and discarded the contaminated basket). The ointments did not help much. When my mother took me along to a an elderly female tailor she saw my wounds and advised my mother to take me to the healer just next door, while we are already nearby. Mother agreed in order not to contradict the tailor. The elderly person murmured a very short prayer looking at me, took two voluminous pebbles from his worn-out wallet and just before my face stroke them one against the other three times in succession. Sparks came out and the session was over. I never came across this pebble-striking method in related literature and I consider it a unique method worth of mentioning here.

\section{Further Folk Beliefs}

Many superstitions have historical roots. Tuesday is said to be an unlucky day for important undertakings.
In Turkish coincidentally Sall (Tuesday) and sallanmak (to shake or swing) are phonetically related. This reinforces the belief. Bayrı [4] writes that the belief stems from Istanbulites but earlier from Byzantium subjects since the city succumbed to the army of Mehmed the Second on a Tuesday. He says, on the contrary, it must be a lucky day for Moslem Turks.

Folk beliefs depend on the specific region in question and are too numerous to collect together in a single article like this. In Bilecik for instance looking at a mirror at night time is believed to make one go crazy or fill one's face with freckles. Chewing gum or cutting fingernails at night bring bad luck also [5].

In Burhaniye the crushing majority of folk beliefs are concentrated around gates and thresholds. Good or bad effects from outside enter the house from here. Sometimes necessary measures are taken to enhance the influx of good effects and at certain other times and situations the reverse is done to prevent the inflow of undesired effects. The gate has a predominant place in people's minds [6].

\section{Beliefs About Hidden Treasures}

In villages, many beliefs also turn around hidden treasures. "A widespread treasure belief in Turkey is that of money being hidden in the walls or columns of mosques and other public buildings by their builders for future repair expenses and this leads to considerable destruction" [7]. "There are two types of treasure hunters in Turkey: the urban and the rural. The peasant treasure hunter can not of course read and understand profound [occult] works of medieval learning [believed to lead the way to treasures] but he often consults some 'deep hodja' for that purpose" [7].

In an autobiographical novel (the Bridge of Lüleburgaz) the author with the pen name Tayyar Tahiroğlu mentioned about his childhood memories in the village in 1930s. His father obliged him to read maps of hidden treasure from the bottom of a bowl filled with water. (I had the book but lost it). The father is a hard man and based on a few omens he had 
observed he believes his small innocent son should be able to communicate with spiritual beings. The child feels crushed under this responsibility but can do nothing but playing alone. The bridge legs are the main obsession of the father as locations to dig around [8].

In Çankırı a janitor working for a government office was a treasure hunter. He was from a village of Şabanözü (the hometown of honorable Professor Hasan Ünal Nalbantoğlu as he revealed once to me). The janitor once confined to me that some treasures were under the protection of djinns, which further complicate their discovery.

When I was an engineer working for the state-owned fertilizer plant in Kütahya, one night I had to relieve myself in open air. When I was talking with a factory watchman of peasant origins, I inferred that he must have seen me then, because he skillfully drifted the topic to urinating in the open. He said that it is dangerous practice and a djinn can strike you. While mentioning those entities he did not neglect to say the necessary mystical formula either (let them be in their good hour).

\section{They, Nevertheless, are Rational People!}

I remember some field work dating back to 1970's where peasants in southern regions were asked by the researchers if they thought using tractors and other equipment were sinful. They reacted with indignation and answered with counter-questions like "do you think we are stupid just because we are peasants?". (With some reserve I vaguely remember the name of Deniz Kandiyoti as being one of the co-authors at the time).

The Amish society in Pennsylvania may well have their own grounds to avoid the use of technology but Turkish peasants definitely have no similar problems. They are on good terms with any technology they can afford to attain. The peasants are shrewd, wise and they have a certain education enough to get by even when they live in urban centers.

Returning from my recent Aegean trip with my next seat travel companion villager Ahmet the Roll Bread Baker, I philosophized when the bus approached the Dardanelles. I said "straits could present themselves as very keen boundaries; one such strait at the western end of the Mediterranean Sea separates the Islamic Berber communities from Catholic Spaniards, two entirely different worlds". He came up with the name of that strait. "Cebel-i Tarik", he said "as I remember from the fifth and last year of my schooling". I got impressed and also ashamed for underestimating his knowledge of geography. (While crossing the strait on a ferry we got off and smoked, mutually conspiring to pretend that we did not know that the whole ferry was a non-smoking "territory". When a security man warned us we took our last quick puffs and extinguished the butts).

\section{Conclusions}

It appears that high morale and psychological processes are accompanied with many folk healing methods. In the country side those methods are resorted to out of necessity. Bookish remarks about discrediting them at a throw and advising to go to a specialist only sounds pedantic! It is equivalent to reminding the children to drink their milk (!) before going to sleep at the end of the night programs presented by state theater actor Ergün Uçucu on black and white TV screen many years ago (not a fault of the mild-faced actor himself). Which practicing-doctor, let alone a specialist? Which milk? Under which circumstances ${ }^{(*)}$ ?

A desperately sick person would not hesitate to try any method unless obviously suicidal. Let us listen to a doctor of Anthropology, who had just carried out a research around rural Diyarbakir: Peasants believe in the modern treatment methods for diseases due to

\footnotetext{
* Emergency conditions may occur in other places besides villages like on a battlefield, for instance. A lieutenant-colonel who had fought in the peace operation directed to Cyprus in 1974 by Prime Minister Bülent Ecevit, revealed in a talk session in 1984 that health services had been "not bad but literally non-existent". Probably a lesson was taken and the military medical academy was restructured accordingly, soon after.
} 
natural causes like cold, heat, food and drinks, filth (microbes) and wounds. But in addition to treatment in line with modern methods; behavior tending to please supernatural powers through vow, sacrifice, charity, alms, pray, amulets can not be neglected by the peasantry in secondary plan; since such powers render the person delicate to such illnesses. It should not be forgotten that certain elements in Islam support this opinion and understanding. In Islamic faith Allah knows everything and everything occurs in accordance with His will. Spiritual beings like djinns and fairies are also accepted in the religion of Islam [9].

Today one can not see any snake-oil salesmen deceiving ignorant masses by selling magic formulas to remove stains from clothing or former infamous swindlers like Sülün Osman, who used to sell tower clocks to peasants visiting Istanbul.

When it comes to believing the existence of spiritual entities like the human soul, angels and djinns, this has nothing to do with a backward mentality since they are in accordance with the mainstream orthodox creed of a universal celestial religion. Belief in fate is also in the same category. Even Janissaries when they opposed reforms and accused modern techniques as the invention of infidels were only using this argument as a cover story, protecting their corrupted ways. They were "submerged" in commerce up to neck with no discipline left. The payroll of a Janissary with his name labeled officially $(\text { esami })^{(*)}$ was circulating in the market as a substitute for a stock bond. Goldbricking in face of hard military training was the other factor.

Such are the folk beliefs of peasantry. In spite of every kinds of material deprivation; one can with confidence easily say that modernism has penetrated the countryside when it comes to people's mentality. Today's peasant can never be regarded as backward in that respect. Because the decisive point in classifying a people's mentality as backward or forward essentially lies in their attitudes towards use of technology.

\section{References}

[1] Acipayamli, O. 1982. "Acıpayam'da Halk Hekimliği." [Folk-healing in the County of Acipayam] in Antropoloji (dergi/journal), number 11, Dil ve Tarih-Coğrafya Fakültesi, Ankara, pp. 11-16.

[2] Sunar, Ş. 1961. Köyde Okul [Schooling in the Village], İstanbul: Alp Matbaası.

[3] Makal, M. [Mahmut] 1963. Un Village Anatolien [Bizim Köy], (traduit du Turc par Guzine Dino), Paris: Librairie Plon.

[4] Bayri, M. H. 1947, 1972. Istanbul Folkloru, İstanbul: Baha Matbaas1.

[5] Yalvaç; M. 1984. "Bilecik ve Yöresinde Halk İnançları." [Folk beliefs in and around the District of Bilecik] in Sosyoloji Konferanslarl, Yirminci Kitap[Twentieth Book], İstanbul Üniversitesi Yayını No. 3239, pp. 49-63.

[6] Erden, A. 1978. "Burhaniye Köylerinde Konutla İlgili Adet ve İnanmalar." [Customs and Beliefs Related to Housing in the Villages of Burhaniye] in Antropoloji, number 8, Dil ve Tarih-Coğrafya Fakültesi, Ankara, pp. 53-66.

[7] Uysal, A. E. 1985. "Beliefs and Practices Regarding Hidden Treasure in Turkey." in Erdem, cilt 1, say1 1, Atatürk Kültür Merkezi, Ankara, pp. 97-111.

[8] Tahiroğlu, T. 1984. Lüleburgaz Köprüsü: Bir Çocuğun Tüyler Ürperten Yaşantısı [The Bridge of Luleburgaz: The Horrofying Life of a Child], Serkan Matbaacılik ve Ticaret Ortaklığı, İkiçeşmelik Caddesi, İzmir.

[9] Gençler, A. 1978. "Diyarbakır İlinde Farklı Köy toplumlarının Etnografik İncelenmesi." [The Ethndgraphic Scrutiny of Various Peasant Communitis around the District of Diyarbakir] in Antropoloji, 8. say1, Dil ve Tarih-Coğrafya Fakültesi, Ankara, pp. 77-91.

\footnotetext{
* The Turkish idiom (esamesi bile okunmuyor) meaning "his name is not even mentioned" comes from the Janissary esami, the slip carrying his name in the payroll for his three-monthly salary, ulûfe.
} 


\section{SUPPLEMENT: Some Visual Material}

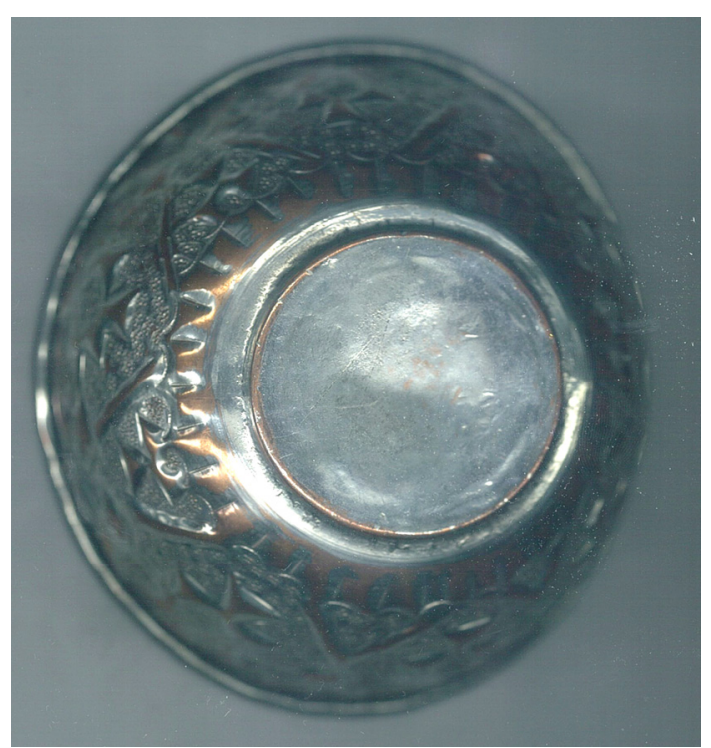

Fig. 1 Molten lead is usually poured into water in copper bowls at a level high above the head of the person, who is to be relived from the evil effects of envious eyes. (Scanned by the author-S.Ç.).

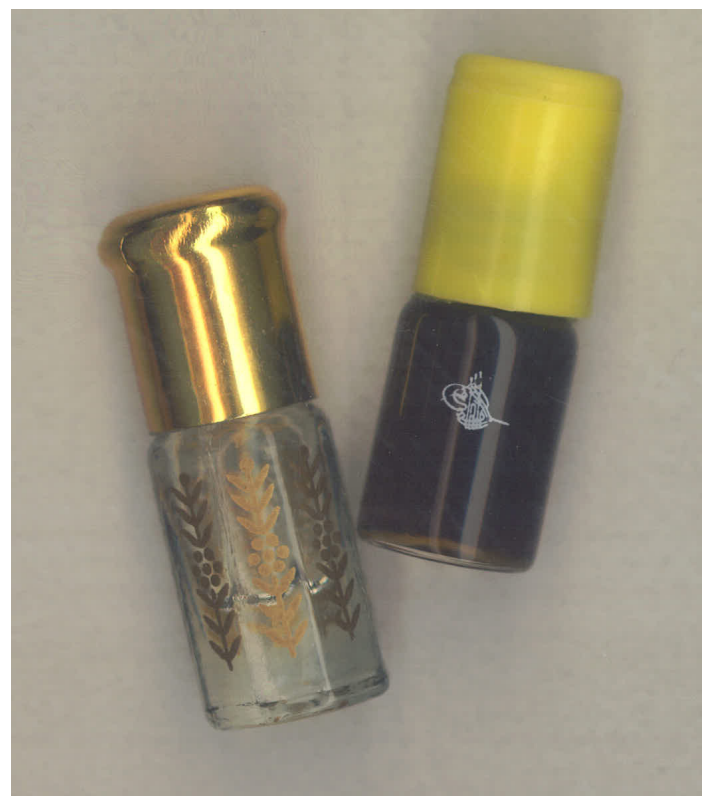

Fig. 2 Tiny flasks with fragrant (non-alcoholic) scent for men. The Blessed Islamic Prophet is known to be fond of pleasant smells. Pleasant smells are supposed to repulse djinns and attract angels. (Scanned by the author-S.Ç.). 


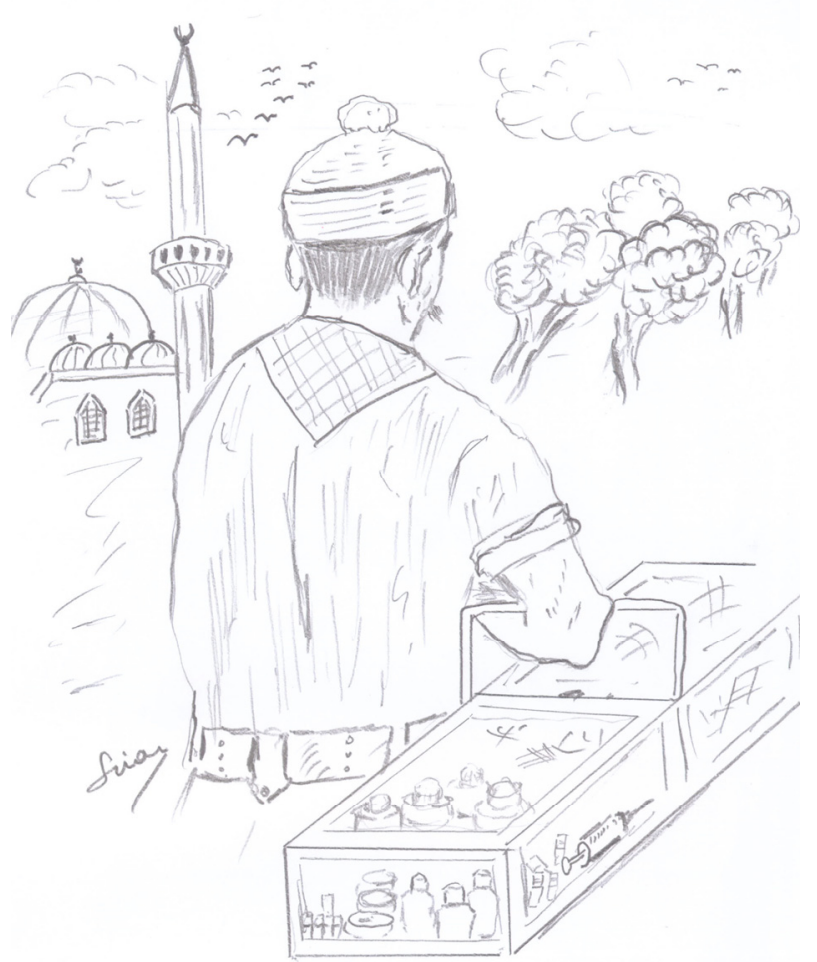

Fig. 3 An itinerant essence vendor who sells scents in his glass-paned wooden box. (The illustration is by the author-S.Ç.).

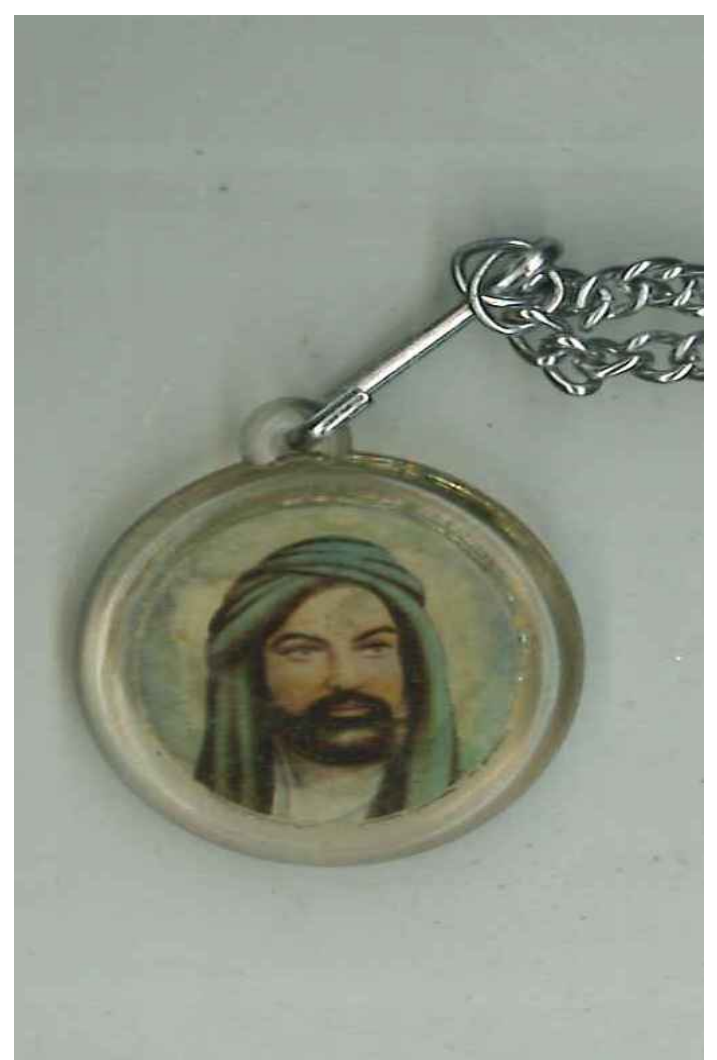

Fig. 4 A medaillon with the representative picture of Hadrat (Venerable) Ali, a prominent apostle of the Blessed Prophet. For Alevite-Moslems Ali is a very important sacred figure. (Scanned by the author-S.Ç.). 


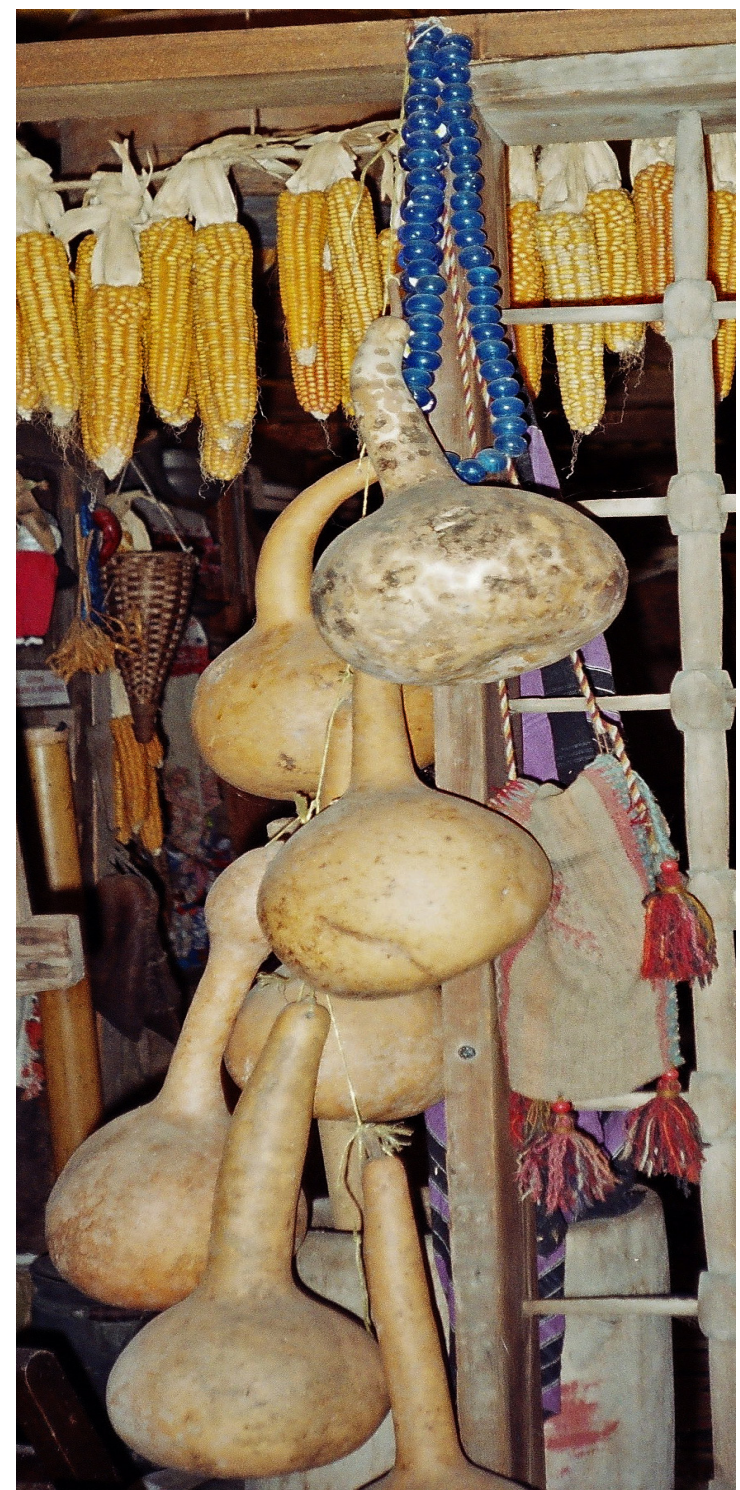

Fig. 5 Dried, emptied water pumpkins used as mugs; corns to be dried and blue beads to cast away possible evil-eye-effects, all in the kitchen of a Black-Sea-house. (Photo by the author-S.Ç.).
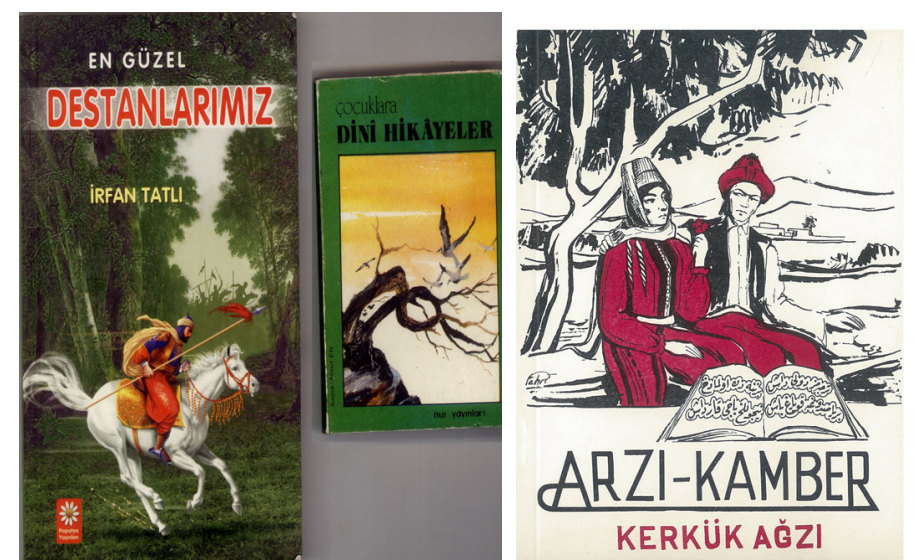

Fig. 6 On long winter nights, the village room (la sale commune) used to serve as a meeting place, where fluent and plain stories praising religious figures and extraordinary folk heroes were read aloud, by literate villagers, and highly enjoyed, publicly. (Scanned by the author-S.Ç.). 


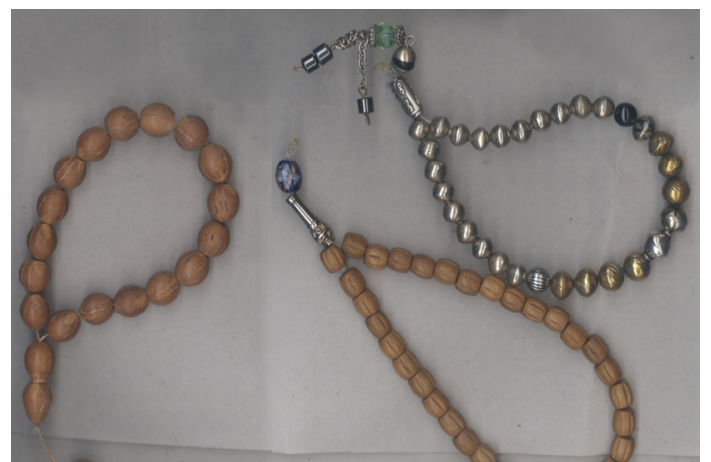

Fig. 7 Telling rosaries (praying beads) is basically an Islamic ritual; but males also indulge in the act as an anti-depressive habitude against sheer boredom. (Scanned by the author-S.Ç.).

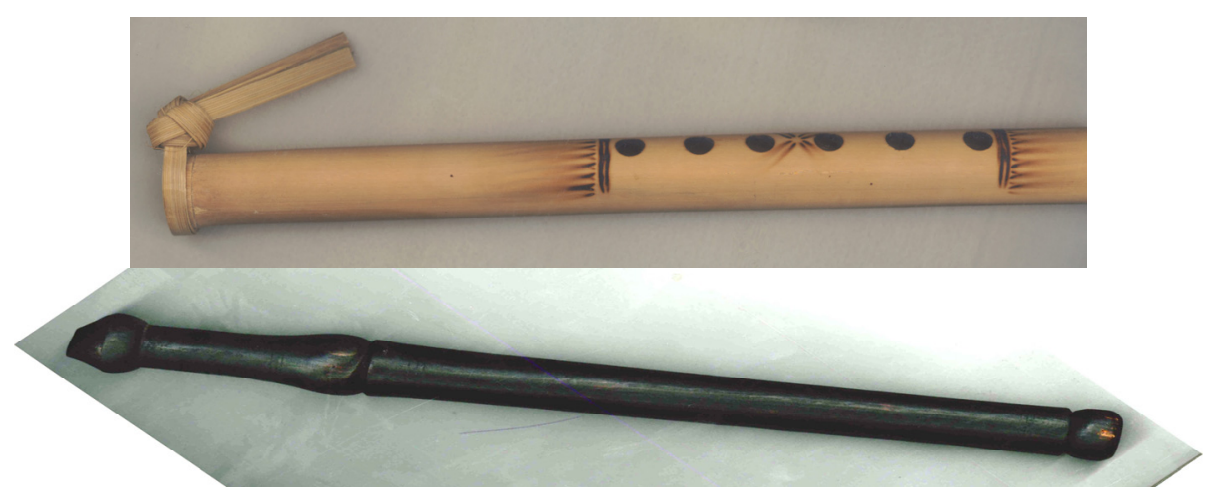

Fig. 8 Authentic shepherd flutes.Shepherds used to carve their own flutes from tree branches. Shepherds suffer constant loneliness and playing the flute alleviates the lonesome feeling. Prophets Jacob, Isaac and Moses were also shepherds by profession. The occupation is held in high esteem and many legends involve shepherds as abstinent, saintly men causing wonders to happen. (Scanned by the author-S.Ç.). 